\title{
Kinetics of Surfactin Production by Bacillus subtilis in a 5 L Stirred-tank Bioreactor
}

(Kinetik Penghasilan Surfaktin oleh Bacillus subtilis dalam Tangki Pengacau Bioreaktor 5 L)

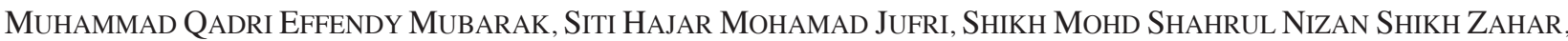 \\ MOHD SAHAID KALIL, AIDIL ABDUl HAMID \& MOHD HAFEZ MOHD ISA*
}

\begin{abstract}
A kinetic model of bacterial growth and metabolite production can adequately explain the trends and interaction of important parameters in a fermentation process. Production of surfactin by two bacterial strains, namely, Bacillus subtilis MSH1 and Bacillus subtilis ATCC 21322, in a 5 L bioreactor was investigated using Cooper's media with 4\% $(v / v)$ glucose. The present kinetic study was carried out in order to determine the correlation between microbial cell growth, surfactin production and glucose consumption. Batch fermentation was performed by cultivation of each selected strain in a bioreactor at $30^{\circ} \mathrm{C}$ for $55 \mathrm{~h}$. The experimental results showed production of surfactin in the culture medium after 5 and 10 h of incubation for B. subtilis ATCC 21332 and B. subtilis MSH1, respectively, at which the bacterial cells were at an early stage of the log phase. The maximum concentration of surfactin $\left(P_{\max }\right)$ achieved by B. subtilis MSHI and B. subtilis ATCC 21332 was 226.17 and $447.26 \mathrm{mg} / \mathrm{L}$, respectively. The kinetic study of bacterial cell growth of both strains indicated that B. subtilis MSHI had a specific growth rate $\left(\mu_{\max }\right)$ of $0.224 \mathrm{~h}^{-1}$ and attained a maximum biomass concentration $\left(X_{\max }\right.$ ) as high as $2.90 \mathrm{~g} / \mathrm{L}$ after $28 \mathrm{~h}$ of fermentation, while B. subtilis ATCC 21332, with $\mu_{\max }$ of $0.087 \mathrm{~h}^{-1}$,attained an $X_{\max }$ of $2.62 \mathrm{~g} / \mathrm{L}$ after $45 \mathrm{~h}$ of incubation. B. subtilis MSH1 showed higher growth kinetics, thus exhibited higher values of $\mu_{\max }$ and $X_{\max }$ compared with $\mathrm{B}$. subtilis ATCC 21332 under identical fermentation conditions. The $P_{\max }$ achieved by B. subtilis ATCC 21332 was $447.26 \mathrm{mg} / \mathrm{L}$, two times higher than that achieved by $\mathrm{B}$. subtilis $\mathrm{MSH} 1(226.17 \mathrm{mg} / \mathrm{L})$. The results obtained provide kinetics information including values of $P_{\max }, \mu_{\max }$ and $X_{\max }$ for better understanding of interactions of bacterial cell growth and glucose consumption towards surfactin production by a commercial strain of B. subtilis ATCC 21332 and a local isolate of B. subtilis MSH1.
\end{abstract}

ABSTRACT

Keywords: Bacillus subtilis ATCC 21322; Bacillus subtilis MSH1; Cooper's media; kinetic study; surfactin production

\section{ABSTRAK}

Model kinetik pertumbuhan bakteria dan penghasilan metabolit boleh menjelaskan aliran dan interaksi parameter yang penting untuk proses penapaian. Penghasilan surfaktin oleh dua jenis bakteria, Bacillus subtilis MSHI dan Bacillus subtilis ATCC 21332; di dalam bioreaktor 5 L telah dikaji menggunakan media Cooper dengan 4\% (v/v) glukosa. Kajian kinetik ini dijalankan bagi menentukan korelasi antara pertumbuhan sel mikrob, penghasilan surfaktin dan penggunaan glukosa. Penapaian bakteria telah dilakukan melalui pengkulturan kedua-dua jenis bakteria di dalam bioreaktor pada $30^{\circ} \mathrm{C}$ selama 55 jam. Keputusan uji kaji menunjukkan penghasilan surfaktin di dalam kultur media B. subtilis ATCC 21332 dan B. subtilis MSH1, masing-masing selepas tempoh pengeraman selama 5 dan 10 jam dengan sel bakteria pada tempoh berkenaan berada pada peringkat awal fasa log. Kepekatan maksimum surfaktin $\left(P_{\max }\right)$ dicapai oleh B. subtilis MSH1 dan B. subtilis ATCC 21332 masing-masing pada 226.17 dan 447.26 mg/L. Kajian kinetik pertumbuhan sel bakteria bagi kedua-dua jenis bakteria menunjukkan bahawa B. subtilis MSH1 memiliki kadar pertumbuhan spesifik $\left(\mu_{\max }\right)$ pada $0.224 \mathrm{~h}^{-1}$ dan mencapai kepekatan maksimum biojisim $\left(X_{\max }\right)$ setinggi 2.90 $\mathrm{g} / \mathrm{L}$ selepas 28 jam tempoh penapaian, manakala B. subtilis ATCC 21332 dengan $\mu_{\max }$ pada $0.087 \mathrm{~h}^{-1}$, mencapai $X_{\max }$ pada $2.62 \mathrm{~g} / \mathrm{L}$ selepas 45 jam tempoh pengeraman. B. subtilis MSH1 menunjukkan kinetik pertumbuhan yang lebih tinggi turut menyebabkan nilai $\mu_{\text {max }}$ dan $X_{\text {max }}$ menjadi lebih tinggi berbanding B. subtilis ATCC pada kaedah penapaian yang sama. Nilai $P_{\max }$ yang dicapai oleh B. subtilis ATCC 21332 adalah $447.26 \mathrm{mg} / \mathrm{L}$, dua kali ganda lebih tinggi daripada yang dicapai oleh B. subtilis MSHI (226.17 mg/L). Keputusan yang diperoleh telah menyediakan maklumat kinetik penting termasuk nilai $P_{\max }, \mu_{\max }$ dan $X_{\max }$ untuk menyumbang pemahaman mengenai interaksi pertumbuhan sel bakteria dan penggunaan glukosa terhadap pengeluaran surfaktin oleh bakteria komersil B. subtilis ATCC 21332 dan pencilan tempatan B. subtilis MSHI.

Kata kunci: Bacillus subtilis ATCC 21332; Bacillus subtilis MSH1; kajian kinetik; media Cooper; penghasilan surfaktin 


\section{INTRODUCTION}

Surfactants, either chemically or biologically produced, are defined as surface active agents with attractive wide-ranging properties (Al-Araji et al. 2007). Surfactants produced by biological synthesis are known as biosurfactants and can be synthesized by a variety of bacteria, yeasts, and fungi through utilization of various carbon feedstocks (Chen et al. 2007). Biosurfactants offer various advantages such as being less toxic, more biodegradable and environmentally friendly compared to chemical surfactants and unlike chemical surfactants, they do not lose their physiochemical properties at different temperatures and $\mathrm{pH}$ levels (Mulligan 2005). Banat et al. (2010) and Ramirez et al. (2015) both mentioned that biosurfactants made using renewable resources through biological process are more compatible and biodegradable towards environment compared to synthetic surfactants.

Among the many classes of biosurfactants, the lipopeptide group is attracting great interest because of its high surface activity and therapeutic potential (Nitschke \& Pastore 2006). Surfactin is one of the most efficient biosurfactants known so far and belongs to the lipopeptide group (Wei et al. 2007). Surfactin exhibits diverse biological activities such as antimicrobial (Fernandes et al. 2007), hemolytic, antifungal, antiviral, and antimycoplasma properties (Singh \& Cameotra 2004). B. subtilis is a sporulating rod bacterium that is one of the most studied Gram-positive bacteria (Driks 2002). It is found in the soil and known to be non-pathogenic in humans and has a wide range of applications (Zweers et al. 2008). The ability of $B$. subtilis strains to produce lipopeptide has been well documented over the last 50 years (Xiao et al. 2008) and has shown great potential for applications in pharmaceutical and biotechnological fields in recent years (Kowall et al. 1998; Mulligan 2005; Sousa et al.2014). Therefore, identifying new strains of surfactin producers and knowledge of the kinetics of surfactin production can improve surfactin yield efficiency and can assist in reducing the total cost of surfactin production.

Measurement of process parameters in fermentation technology has been well investigated (Danielsson 1991). Monitoring of the fermentation process includes use of a wide range of analytical methods to efficiently control fermentation processes (Bradley et al. 1991; Danielsson1991). The determination of reliable kinetic constants of a fermentation process is a difficult task due to limitations in the usual laboratory procedures to measure biomass, substrate concentrations and also due to the dynamic response of the cells under different environmental conditions. On-line monitoring systems are frequently used as the main source of information for the observation of process behavior, combined with model-based calculation for investigation of fermentation conditions (Dondo 2001). It is therefore important to have accurate and consistent set of approaches for measurement of key parameters in fermentation.

Carbon source and metabolic by-products of the fermentation process can affect the yield and quality of the desired product. Thus, it has been found that carbohydrates such as glucose are vital sources for microbial cell growth and biosurfactant production (Casas et al. 1997). Hence, it is important to characterize the key role of the carbon source in the fermentative bioprocess for surfactin production through optimization of fermentation media (Hanko \& Rohrer 2000). Therefore, the development of a fermentation process model for up scaling and bioreactor design is necessary. Several patterns of biosurfactant production by fermentation are possible, depending on the nature of the biosurfactant and the producing microorganism (Rodrigues et al. 2006). Kinetic equations that describe the growth of a microorganism on a substrate are important factors in understanding the phenomena of bioprocess. A variety of mathematical models have been proposed to describe the dynamics of metabolism of a microbial population towards the bioproduct (Okpokwasili $\&$ Nweke 2008). The Monod equation has been widely used to describe growth-linked substrate utilization. However, there is limited references can be referred in the literature regarding a kinetic model to describe surfactin production.

Studies from Isa et al. (2007) have shown that the analytical data being compared was based on the relationship between bacterial growth and surfactin concentration. However, a kinetic model should be developed to explain the substrate and product evolutions under operational fermentation conditions (Rodrigues et al. 2006). Hence, this study aimed to elucidate the basic concept of kinetic model describing biomass cell growth, substrate (glucose) consumption and surfactin production in the batch fermentation process by $B$. subtilis MSH1 and $B$. subtilis ATCC 21322 using a stirred submerged bioreactor.

\section{MATERIALS AND METHODS}

\section{PREPARATION OF FERMENTATION MEDIA}

Unless stated otherwise the defined mineral salts medium (MSM) was used as fermentation media as described by Cooper et al. (1981). The mineral salts media (MSM) consisted of $\mathrm{NH}_{4} \mathrm{NO}_{3} 0.05 \mathrm{M} ; \mathrm{Na}_{2} \mathrm{HPO}_{4}, 0.04 \mathrm{M} ; \mathrm{KH}_{2} \mathrm{PO}_{4}$, $0.03 \mathrm{M} ; \mathrm{CaCl}_{2}, 7.0 \times 10^{-6} \mathrm{M} ; \mathrm{FeSO}_{4} \cdot 7 \mathrm{H}_{2} \mathrm{O}, 4.0 \times 10^{-6} \mathrm{M}$; EDTA, $4.0 \times 10^{-6} \mathrm{M} ; \mathrm{MgSO}_{4}, 8.0 \times 10^{-6} \mathrm{M}$; and $4 \%(\mathrm{w} / \mathrm{v})$ glucose (Davis et al. 2001; Isa et al. 2008). Prepared medium was sterilized by autoclaving at $121^{\circ} \mathrm{C}$ for 15 min prior to fermentation.

\section{CULTURE CONDITONS AND FERMENTATION}

B. subtilis MSH1 was isolated from oil contaminated soils collected at selected vehicle workshops in Kajang (Selangor), Malaysia and was identified as a B. subtilisproducer of surfactin through $16 \mathrm{~S}$ rDNA gene sequencing (accession no. JX080184.1) and sfp gene sequencing (accession no.CP002183.1) by Shannaq and Isa (2013). $B$. subtilis ATCC 21332 is a commercial strain that has been confirmed as an active surfactin producer from previous 
studies (Shannaq \& Isa 2013). Two loopfuls of grown bacterial cells from the nutrient agar were transferred into $25 \mathrm{~mL}$ of nutrient broth containing $40 \mathrm{~g} / \mathrm{L}$ glucose, followed by incubation at $30^{\circ} \mathrm{C}$ for $24 \mathrm{~h}$ by shaking at 200 $\mathrm{rpm}$. A volume of $5 \mathrm{~mL}$ of the cultured broth was then transferred to a conical flask containing 45 mL of Cooper's medium (Cooper et al. 1981). A total of five conical flasks were incubated using the same conditions for $16 \mathrm{~h}$. A total volume of $250 \mathrm{~mL}$ was used to inoculate $4750 \mathrm{~mL}$ of Cooper's media (Isa et al. 2007).

A submerged bioreactor (Sartorius Stedim, Germany) with a working volume of $5 \mathrm{~L}$ was used for fermentation to produce surfactin. The bioreactor is equipped with an agitation system with two impellers on a single drive shaft connected to a motor. Agitation speed, dissolved oxygen and $\mathrm{pH}$ were controlled by a fermentation control unit. The $\mathrm{pH}$ of the cultured broth was maintained by automatic addition of $1.0 \mathrm{M} \mathrm{NaOH}$ and $1.0 \mathrm{M} \mathrm{HCl}$. The fermentation conditions were set at a temperature of $30^{\circ} \mathrm{C}$, agitation speed of $100 \mathrm{rpm}$, air flow rate of $1 \mathrm{vvm}^{-1}$, and $\mathrm{pH} 7$ for 55 h. These conditions were employed for cultivation of $B$. subtilis MSH1 and B. subtilis ATCC 21332 with a low level of dissolved oxygen (Isa et al. 2007). Cultured broth samples were withdrawn aseptically every $4 \mathrm{~h}$ for determination of bacterial growth, surfactin concentration and glucose consumption.

\section{DETERMINATION OF BACTERIAL GROWTH RATE, SURFACTIN AND GLUCOSE CONCENTRATIONS}

Bacterial growth rate Bacterial growth was measured by determining the biomass concentration (gram of dry cell weight per liter of culture medium) at various time intervals for every $4 \mathrm{~h}$ to $55 \mathrm{~h}$. Fixed volumes $(20 \mathrm{~mL})$ of the culture samples were centrifuged at $10,000 \times \mathrm{g}$ for 10 min to pellet down the biomass. The biomass were ovendried up to $105^{\circ} \mathrm{C}$ for $24 \mathrm{~h}$ and weighed.

Surfactin concentration Cultured samples were withdrawn aseptically every $4 \mathrm{~h}$ and centrifuged at $10,000 \times \mathrm{g}$ for $10 \mathrm{~min}$. The supernatant was then filtered through a $0.2 \mu \mathrm{m}$ nylon filter membrane for surfactin and glucose analyses. Surfactin concentration was determined using high-performance liquid chromatography (HPLC; Agilent Technologies, 1200 Series, USA) equipped with Chromolith ${ }^{\circledR}$ high performance RP-18 $(100 \times 4.6 \mathrm{~mm}, 5 \mu \mathrm{m})$ and detected at $205 \mathrm{~nm}$ with a variable wavelength detector (VWD). Mixtures of mobile phase consisting of acetonitrile (ACN) and $3.8 \mathrm{mM}$ trifluoroacetic acid (TFA) solutions at the ratio of 80:20 were pumped using an isocratic mode at a flow rate of $2.2 \mathrm{~mL} / \mathrm{min}$. The sample injection was set at $30 \mu \mathrm{L}$ and the duration of each analysis was within $8 \mathrm{~min}$. Surfactin at $98 \%$ purity (Sigma Aldrich, United States) was used as a standard.

Glucose concentration Glucose was measured by HPLC equipped with Chromolith ${ }^{\circledR} \mathrm{NH} 2 \mathrm{RP}-18(100 \times 4.6 \mathrm{~mm}, 5$ $\mu \mathrm{m})$ and detected at $195 \mathrm{~nm}$ with a VWD. The mobile phase used was $3.8 \mathrm{mM}$ TFA and was pumped with an isocratic mode at a flow rate of $0.5 \mathrm{~mL} / \mathrm{min}$. The total elution time for analysis was within $8 \mathrm{~min}$.

\section{CALCULATION OF KINETIC PARAMETERS}

Substrate conversion was calculated according to (1)

$$
\Delta S(\%)=\frac{S_{0}-S}{S_{0}} \times 100
$$

where $\mathrm{S}_{\mathrm{o}}$ is the initial glucose concentration; and $\mathrm{S}$ is the glucose concentration in the samples at each time interval.

The volumetric productivity $\left(\mathrm{P}_{\mathrm{p}}\right.$ and $\left.\mathrm{P}_{\mathrm{x}}\right)$ was calculated as the ratio of maximum surfactin $\left(\mathrm{P}_{\max }\right)$ or cell concentration $\left(\mathrm{X}_{\max }\right)$ to the fermentation time when the maximum concentration of surfactin was achieved $\left(t_{P \max }\right.$ and $\mathrm{t}_{\mathrm{Xmax}}$, respectively):

$$
\begin{gathered}
P_{p}=\frac{P_{\max }}{t_{P_{\max }}} . \\
P_{x}=\frac{X_{\max }}{t_{X_{\max }}} .
\end{gathered}
$$

The yield of surfactin on glucose $\left(\mathrm{Y}_{\mathrm{P} / \mathrm{S}}, \mathrm{g} / \mathrm{g}\right)$ was defined as:

$$
Y_{p / s}=\frac{P_{f}-P_{o}}{S_{f}-S_{o}} .
$$

The yield of cell mass on glucose $\left(\mathrm{Y}_{\mathrm{X} / \mathrm{S}}, \mathrm{g} / \mathrm{g}\right)$ was defined as:

$$
Y_{x / s}=\frac{X_{f}-X_{o}}{S_{f}-S_{o}} .
$$

The yield of surfactin on cell mass $\left(\mathrm{Y}_{\mathrm{P} / \mathrm{X}}, \mathrm{g} / \mathrm{g}\right)$ was defined as:

$$
Y_{P / X}=\frac{P_{f}-P_{o}}{X_{f}-X_{o}},
$$

where $P_{o}, X_{o}, S_{o}$ are the initial amount of surfactin concentration; biomass concentration; and glucose concentration, respectively. In addition $P_{f}, X_{f}, S_{f}$ represent the amount of surfactin, biomass and glucose concentration in the samples for each of the time interval, respectively.

\section{RESULTS}

\section{BACTERIAL CELL GROWTH IN COOPER'S MEDIUM}

Figures 1 and 2 show the bacterial cell growth for $B$. subtilis MSH1 and B. subtilis ATCC 21332, repectively. The duration of cell growth (lag phase) for B. subtilis MSH1 and B. subtilis ATCC 21332 lasted approximately for 5 and $10 \mathrm{~h}$, respectively, implying that $B$. subtilis MSH1 
requires less than $5 \mathrm{~h}$ to adapt to the medium. An obvious pattern of the lag phase can be seen for B. subtilis ATCC 21332 , in which the strain needed $10 \mathrm{~h}$ to adapt to the medium. This lag phase showed almost no apparent cell growth, due to adaptation of the microorganism to the new environment. Later, cell growth entered the exponential phase, when cell numbers increased in a logarithmic pattern. As shown in Figures 1 and 2, the exponential phase for B. subtilis MSH1 was between 5 and $28 \mathrm{~h}$, while the exponential phase for B. subtilis ATCC 21332 was between 10 and $45 \mathrm{~h}$. In this phase, about $65 \%$ of the initial glucose $\left(\mathrm{S}_{\mathrm{o}}\right)$ was consumed by both strains and the maxiumum glucose consumption occurred in this phase. This phase was shorter for B. subtilis MSH1 (23 h) than B. subtilis ATCC $21332(35 \mathrm{~h})$, indicating that $B$. subtilis MSH1 achieved the maximum cell growth $12 \mathrm{~h}$ earlier than B. subtilis ATCC 21332. As is evident from Figures 1 and 2, the stationary growth phase for B. subtilis MSH1 began after $28 \mathrm{~h}$ of incubation, while the stationary phase for B. subtilis ATCC 21332 began after $45 \mathrm{~h}$.

\section{B. subtilis ATCC 21332}

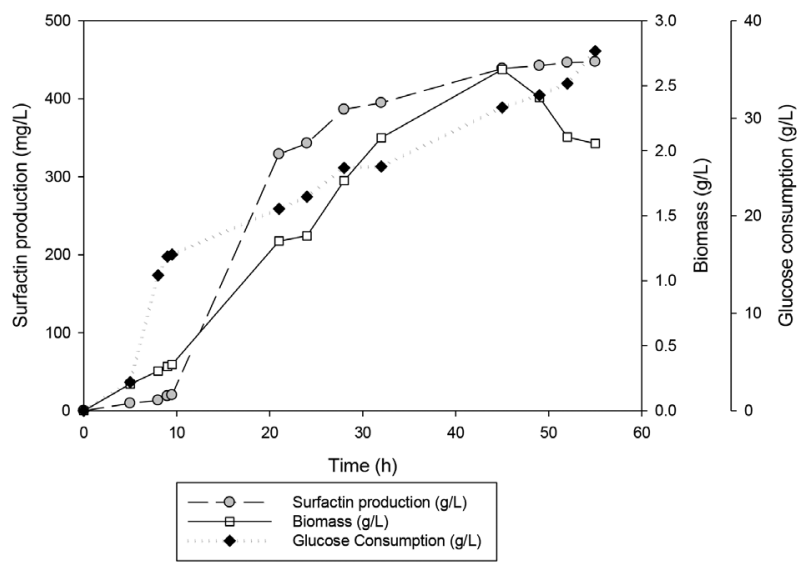

FIGURE 1. Production of surfactin by B. subtilis ATCC 21332

B. subtilis MSH1

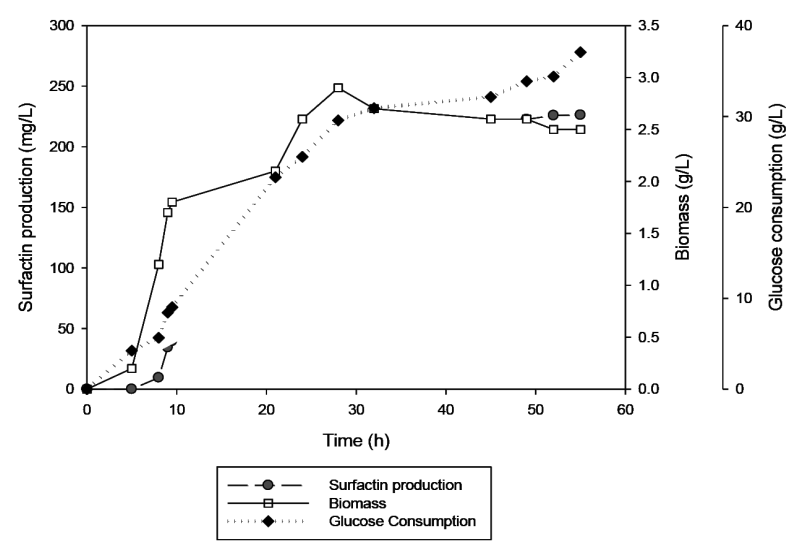

FIGURE 2. Surfactin production by B. subtilis MSH1

\section{KINETICS OF SURFACTIN PRODUCTION BY B. SUBTILIS MSH1 AND B. SUBTILIS ATCC 21332}

Table 1 shows the results obtained from kinetic studies of bacterial growth, glucose consumption and surfactin production by $B$. subtilis MSH1 and B. subtilis ATCC 21332. The growth rate of $B$. subtilis MSH1 varied from $0.106 \mathrm{~h}^{-1}$ to $0.224 \mathrm{~h}^{-1}$ while that of $B$. subtilis ATCC 21332 varied from $0.048 \mathrm{~h}^{-1}$ to $0.087 \mathrm{~h}^{-1}$. The biomass specific growth rate $\left(\mu_{\max }\right)$ for $B$. subtilis MSH1 was as high as $0.224 \mathrm{~h}^{-1}$, two times higher than that for B. subtilis ATCC $21332\left(0.087 \mathrm{~h}^{-1}\right)$. This implies that $B$. subtilis MSH1 was better adapted to Cooper's medium. The highest biomass concentration $\left(\mathrm{X}_{\max }\right)$ shown by B. subtilis MSH1 was at $2.90 \mathrm{~g} / \mathrm{L}$, compared to B. subtilis ATCC 21332 (2.62 g/L) thus confirming the higher $\mu_{\max }$ for $B$. subtilis MSH1.

\section{DISCUSSION}

\section{BACTERIAL CELL GROWTH IN COOPER'S MEDIUM}

Various Bacillus sp. strains such as B. atrophaeus ATCC 9372 (Neves et al. 2007), B. subtilis C9 (Kim et al. 1997), B. subtilis LAMI005 (de Oliveira et al.2013) and B. subtilis 20B (Joshi et al. 2008) have been reported as surfactin producers. In spite of the ability to produce competitive amounts of surfactin (Shannaq \& Isa 2013), B. subtilis MSH1 is a local strain that has not been extensively studied and used for the production of surfactin. In contrast, $B$. subtilis ATCC 21332 is commercially known as a surfactin producer and is able to produce surfactin in different types of substrate and media, such as potato substrate (Fox \& Bala 2000), clarified cashew apple juice (de Oliveira et al. 2013) and Cooper's media (Isa et al. 2007; Cooper et al. 1981). Cooper's media with $4 \%(w / v)$ glucose was used in the present study because it has been designed to supply nutrients for bacterial cell growth and surfactin synthesis by Bacillus strains (Cooper et al. 1981; Davis et al. 2001; Isa et al. 2007; Yakimov et al. 1997). The $\mathrm{pH}$ of fermentation broth was maintained at $\mathrm{pH} 7$ to prevent acidification of the culture medium. Reduction of $\mathrm{pH}$ to less than $\mathrm{pH} 5$ causes precipitation of surfactin due to loss of solubility (Wei et al. 2003). Cooper et al. (1981) and Kim et al. (1997) suggested that biosurfactant production by $B$. subtilis strains was highly related to microbial cell growth, while Shepard and Mulligan (1987) stated that biosurfactant production mainly occurred at the end of the exponential phase or in the stationary phase of microbial growth. Based on Figures 1 and 2, the production of surfactin was closely related to growth of the bacterial strains where maximum production occurred at the end of the exponential growth phase for both strains.

\section{RELATIONSHIP BETWEEN SURFACTIN PRODUCTION, CELL GROWTH, AND GLUCOSE CONSUMPTION}

Both strains of B. subtilis produced surfactin with a similar pattern during the entire growth phase except for the log phase. Surfactin production by $B$. subtilis MSH1 and $B$. 


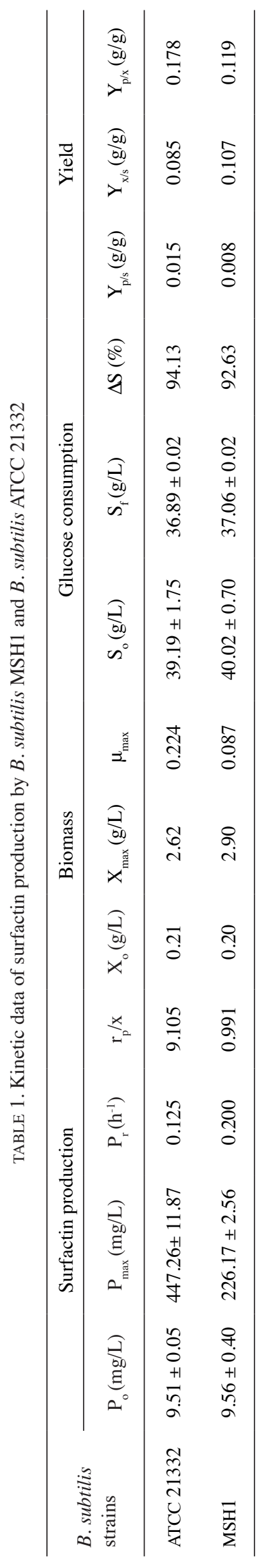


subtilis ATCC 21332 started at early exponential growth phase (Figures $1 \& 2$ ). The cell growth was slow and glucose consumption was also very low at the early exponential growth phase. Only about $10 \%$ of $\mathrm{S}_{\mathrm{o}}$ was consumed by both strains, considering the fact that surfactin is categorized as a secondary metabolite (Georgiou et al. 1992). For $B$. subtilis ATCC 21332, surfactin was produced as cells began to enter the stationary phase of growth and the maximum concentration was attained at the end of the exponential phase, as the glucose concentration became lower due to consumption by the cells (Davis et al. 1999). The maximum surfactin concentration $\left(\mathrm{P}_{\max }\right)$ for both strains was attained during the stationary phase, reaching values as high as 447.26 and $226.17 \mathrm{mg} / \mathrm{L}$ for B. subtilis ATCC 21332 and $B$. subtilis MSH1, respectively. This finding corroborates that from a study by Nitschke and Pastore (2006) using $B$. subtilis LB5a, grown in cassava waste fermentation media. In addition, a previous fermentative study using $B$. subtilis ATCC 21332 on various media showed that the highest surfactin concentration was attained in the stationary phase (Kim et al. 1997; Mulligan et al. 2005; Yakimov et al. 1997). In this phase, most of the glucose feedstock $\left(\mathrm{S}_{\mathrm{o}}\right)$ has been consumed by the strains. A study conducted by Alonso et al. (2016) showed a better impact towards surfactin production by harvesting cells from the culture at the early exponential growth, mid-exponential growth and late exponential growth through foaming process compared to non-foamed cells.

The $\mathrm{P}_{\max }$ value for $B$. subtilis ATCC 21332 was approximately $447.26 \mathrm{mg} / \mathrm{L}$, two times higher than $B$. subtilis MSH1 (226.17 mg/L) under the same fermentation conditions. B. subtilis MSH1 had $5 \mathrm{~h}$ of lag phase to quickly adapt to Cooper's media, which caused it to achieve $\mathrm{P}_{\max }$ in a shorter time than B. subtilis ATCC 21332. A previous fermentative study using $B$. subtilis LAMI005 showed that the initial concentration of medium formulated with clarified cashew apple juice supplemented with $1.0 \mathrm{~g} / \mathrm{L}$ of $\left(\mathrm{NH}_{4}\right)_{2} \mathrm{SO}_{4}$ and distilled water affected the maximum cell concentration (de Oliveira et al. 2013). The result obtained indicated the ability of crude biosurfactant to decrease surface tension of water along with critical micelle concentration using the medium formulated with the best nutrients.

\section{KINETICS OF SURFACTIN PRODUCTION BY B. SUBTILIS MSH1 AND B. SUBTILIS ATCC 21332}

As shown in Table 1, the biomass yield $\left(\mathrm{Y}_{\mathrm{x} / \mathrm{s}}\right)$ produced by $B$. subtilis MSH1 $(0.107 \mathrm{~g} / \mathrm{g})$ was $27 \%$ higher than $B$. subtilis ATCC $21332(0.085 \mathrm{~g} / \mathrm{g})$, indicating that B. subtilis MSH1 showed higher growth kinetics when compared to $B$. subtilis ATCC 21332, with higher values of $\mu_{\max }, \mathrm{X}_{\max }$, and $\mathrm{Y}_{\mathrm{x} / \mathrm{s}}$. This could be due to the type of organism as B. subtilis MSH1 easily adapted to Cooper's medium in comparison with $B$. subtilis ATCC 21332 . As mentioned in a previous study, the type of organism and the culture medium are known to be the main factors for microbial growth pattern (de Oliveira et al. 2013).
The initial production of surfactin $\left(\mathrm{P}_{\mathrm{o}}\right)$ for $B$. subtilis MSH1 and for B. subtilis ATCC 21332 were 9.56 and $9.51 \mathrm{mg} / \mathrm{L}$, respectively, when $33 \%$ of the total glucose had been consumed. The results showed that cell concentration $(\mathrm{X})$ and volumetric biomass productivity $\left(\mathrm{P}_{\mathrm{x}}\right)$ increased with increasing sugar consumption during the fermentation time, until the maximum biomass $\left(\mathrm{X}_{\max }\right)$ was reached. As shown in Table $1, \mathrm{P}_{\max }$ attained by $B$. subtilis ATCC 21332 and for B. subtilis MSH1 were 438.64 \pm 11.87 and $226.17 \pm 5.62 \mathrm{mg} / \mathrm{L}$, respectively. Similar findings have been reported by Davis et al. (2001), in a study of surfactin recovery using foam fractionation which showed the production of surfactin $\left(\mathrm{P}_{\max }\right)$ by $B$. subtilis ATCC 21332 to be around $439 \mathrm{mg} / \mathrm{L}$. Another study by Isa et al. (2007) also showed the higher $\mathrm{P}_{\max }$ at $583 \mathrm{mg} / \mathrm{L}$ under the same experimental conditions. $B$. subtilis MSH1 which was locally isolated had lower $\mathrm{P}_{\max }$ value compared with the commercial strain B. subtilis ATCC 21332, whose $\mathrm{P}_{\max }$ was approximately two times greater and regularly used as an active surfactin producer. Glucose is a good carbon source for fermentative study of biosurfactant production by Bacillus strains and is widely used in many studies (Cooper et al. 1981; Davis et al. 2001, 1999; de Oliveira et al. 2013; Isa et al. 2008, 2007). The carbon source supplied is able to assist the production of surfactin (de Oliveira et al. 2013). It must be supplied in the medium up to the optimum level of $65.04 \mathrm{~g} / \mathrm{L}$. Considerable amount of glucose was consumed by both strains when the $\mathrm{P}_{\mathrm{o}}$ increased to $\mathrm{P}_{\max }$ during the course of fermentation, when the $\mu_{\max }$ for both strains was attained. Alternatively, surfactin production can be evaluated through the yield of biosurfactant on cell mass $\left(\mathrm{Y}_{\mathrm{p} / \mathrm{x}}\right)$ (de Oliveira et al.2013), which is a useful volumeindependent parameter for scaling up the bioprocess (Neves et al. 2007). The $Y_{p / x}$ obtained was 0.178 and $0.119 \mathrm{~g} / \mathrm{g}$ for B. subtilis MSH1 and B. subtilis ATCC 21332, respectively. The studies conducted by Davis et al. (1999) and de Oliveira et al. (2013) showed that the $\mathrm{Y}_{\mathrm{p} / \mathrm{x}}$ value ranged from 0.0068 to $0.075 \mathrm{~g} / \mathrm{g}$ when $B$. subtilis LAMI005 and B. subtilis ATCC 21332 were cultivated, depending on the intial substrate concentration in the culture medium.

The value of $\mathrm{Y}_{\mathrm{p} / \mathrm{s}}$ shows the relationship between surfactin production and glucose consumption (Table 1). The $\mathrm{Y}_{\mathrm{p} / \mathrm{s}}$ obtained was 0.008 and $0.015 \mathrm{~g} / \mathrm{g}$ for $B$. subtilis MSH1 and B. subtilis ATCC 21332, respectively. $B$. subtilis ATCC 21332 efficiently consumed a high amount of glucose $(87 \%)$ compared with B. subtilis MSH1. High substrate (glucose) consumption by bacterial cells $(93 \%)$ was not limited by the carbon source in the culture medium, because only $66 \%$ of glucose had been consumed when the $\mathrm{P}_{\max }$ was obtained. Davis et al. (1999) found that cultivation of B. subtilis ATCC 21332 in medium with at least $30 \mathrm{~g} / \mathrm{L}$ glucose was adequate to avoid carbon limitation during fermentative activity. It is possible for the strains to use other available nutrients in the culture medium as shown by the increase of bacterial biomass. 
The $r_{p} / X$ reflects the activity of the microorganism in surfactin production (Rodrigues et al. 2006). As shown in Table 1, B. subtilis ATCC 21332 showed a high value of $r_{p} / X(9.105 \mathrm{mg} / \mathrm{Lh})$ when compared to $B$. subtilis MSH1 $(0.991 \mathrm{mg} / \mathrm{Lh})$, implying the higher efficiency of B. subtilis ATCC 21332 in surfactin production (10 times). Surfactin production by both strains was closely related to bacterial growth (Cooper et al. 1981; Kim et al. 1997).

It can be observed from Figures 1 and 2 that cell growth, surfactin production and glucose consumption showed similar profiles for both strains, consistent with a previous study conducted using different types of Bacillus strains (de Oliveira et al. 2013; Kim et al. 1997). Growth-associated production of biosurfactant has been reported for Bacillus licheniformis JF-2 (Lin et al. 1994), B. subtilis C9 (Kim et al. 1997) and B. subtilis LAMI005 (de Oliveira et al. 2013; Sousa et al. 2014;). A direct relationship between biosurfactant production, cell growth and carbohydrate utilization was observed during the production of biosurfactant by B. subtilis $\mathrm{C} 9$ (Kim et al. 1997). Therefore, this study shows the surfactin production by B. subtilis ATCC 21332 and B. subtilis MSH1 were both associated with cell growth hence indicating a strong correlation between surfactin production kinetics and biomass kinetics during bacterial growth for both strains of $B$. subtilis respectively.

\section{CONCLUSION}

This model could be used to assess productivity of any bacterial strain to produce surfactin through correlation of biomass concentration, surfactin concentration and glucose consumption at various stages during the fermentation process. The results obtained showed $B$. subtilis MSH1 as a good alternative surfactin producer in Cooper's media. B. subtilis MSH1 and B. subtilis ATCC 21332 were able to grow in Cooper's medium and produce surfactin in a stirred-tank bioreactor. In spite of the high consumption of glucose at approximately $93 \%$ by both strains, no carbon limitation was observed.

B. subtilis MSH1 showed higher growth cell kinetics, by exhibiting higher values of $\mu_{\text {max }}\left(0.224 \mathrm{~h}^{-1}\right), \mathrm{X}_{\text {max }}(2.90$ $\mathrm{g} / \mathrm{L})$ and $\mathrm{Y}_{\mathrm{x} / \mathrm{s}}(0.107 \mathrm{~g} / \mathrm{g})$ in comparison to the growth kinetics of $B$. subtilis ATCC 21332 by $0.087 \mathrm{~h}^{-1}\left(\mu_{\max }\right), 2.62$ $\mathrm{g} / \mathrm{L}\left(\mathrm{X}_{\max }\right)$ and $0.085 \mathrm{~g} / \mathrm{g}\left(\mathrm{Y}_{\mathrm{x} / \mathrm{s}}\right)$, respectively. Biomass cell productivity of $B$. subtilis MSH1 $\left(0.224 \mathrm{~h}^{-1}\right)$ was found to be approximately three times higher compared to $B$. subtilis ATCC $21332\left(0.087 \mathrm{~h}^{-1}\right)$. On the other hand, B. subtilis ATCC 21332 showed higher surfactin production kinetics, with higher values of $\mathrm{r}_{\mathrm{p} / \mathrm{X}}, \mathrm{P}_{\max }$, and $\mathrm{Y}_{\mathrm{p} / \mathrm{s}}$ compared to B. subtilis MSH1. The maximum surfactin production of $B$. subtilis ATCC 21332 was found to be approximately $447.26 \mathrm{mg} / \mathrm{L}$, two times higher compared with $226.17 \mathrm{mg} / \mathrm{L}$ from $B$. subtilis MSH1 under the same fermentation conditions. It was found that $B$. subtilis MSH1 had of lag phase period of $5 \mathrm{~h}$ and quickly adapted to Cooper's media causing it to attain $\mathrm{P}_{\max }$ in a shorter time than B. subtilis ATCC 21332. In addition, $B$. subtilis MSH1 had lesser value compared with $B$. subtilis ATCC 21332 in terms of yield efficiency of $\mathrm{Y}_{\mathrm{p} / \mathrm{s}}, \mathrm{Y}_{\mathrm{x} / \mathrm{s}}$ and $Y_{p / x}$. The kinetic model proposed using (1) to (4) and the kinetic parameters shown in Table 1 can adequately explain the trends and interaction of all parameters involved during the course of fermentation. Overall, this study provides some significant knowledge of important parameters and its correlation towards surfactin production and can be further extended to other biosurfactant producer strains.

\section{ACKNOWLEDGEMENTS}

The authors would like to thank Universiti Sains Islam Malaysia (USIM) and Ministry of Higher Education (MOHE), Malaysia for funding this research under the internal research grant PPP/USG-0216/FST/30/16716 and ERGS/1/2012/STG08/USIM/02/3.

\section{REFERENCES}

Al-Araji, L., Raja Abd. Rahman, R.N.Z., Basri, M. \& Salleh, A.B. 2007. Microbial surfactant. Asia Pac. J. Mol. Biol. Biotechnol. 15(3): 99-105.

Banat, I.M., Franzetti, A., Gandolfi, I., Bestetti, G., Martinotti, M.G., Fracchia, L., Smyth, T.J. \& Marchant, R. 2010. Microbial biosurfactants production, applications and future potential. Appl. Microbiol. Biotechnol. 87: 427-444.

Bradley, J. \& Schmid, R.D. 1991. Optimisation of a biosensor for in situ fermentation monitoring of glucose concentration. Biosens. Bioelectron 6: 669-674.

Casas, J., Garcia, D.L.S. \& Garcia-Ochoa, F. 1997. Optimization of a synthetic medium for Candida bombicola growth using factorial design experiment. Enzyme Microb. Tech. 21: 221-229.

Chen, C., Bake, S. \& Darton, R. 2007. The application of a high throughput analysis method for the screening of potential biosurfactant from natural source. J. Microbiol. Meth. 70: 503-510.

Cooper, D., Macdonald, C.R., Duff, S. \& Kosaric, N. 1981. Enhance production of surfactin from Bacillus subtilis by continuos product removal and metal cation addition. J. Appl. Environ. Microbiol. 42: 408-412.

Danielsson, B. 1991. Fermentation monitoring. Curr. Opin. Biotech. 2: 17-22.

Davis, D., Lynch, H. \& Varley, J. 2001. The application of foaming for the recovery of surfactin from B. subtilis ATCC 21332 cultures. Enzyme Microb. Tech. 28: 346-354.

Davis, D., Lynch, H. \& Varley, J. 1999. The production of surfactin in batchculture by Bacillus subtilis ATCC 21332 is strongly influenced by the conditions of nitrogen metabolism. Enzyme Microb. Tech. 25: 322-329.

de Oliveira, F.D.W., Franca, I.W.L., Felix, A.K.N., Martins, J.L., Giro, M.E.A., Melo, V.M.M. \& Goncalves, L.R.B. 2013. Kinetic study of biosurfactant production by Bacillus subtilis LAM005 grown in clarified cashew apple juice. Colloid Surface B 101: 34-43.

Dondo, R.G. 2001. A method for detection and diagnosis on batch fermentations. ISA Transactions 42(1): 135-147.

Driks, A. 2002. Overview: Development in bacteria: Spore formation in Bacillus subtilis. Journal of Cellular and Molecular Life Sciences 59: 389-391. 
Fernandes, P., de Aruda, I. \& dos Santos, A. 2007. Antimicrobial activity of surfactants produced by Bacillus subtilis R14 against multidrug bacteria. Braz. J. Microbiol. 38: 704-709.

Fox, S.L. \& Bala, G.A. 2000. Production of surfactant from Bacillus subtilis ATCC 21332 using potato substrate. Bioresource Technol. 75: 235-240.

Georgiou, G., Lin, S. \& Sharma, M. 1992. Surface-active compounds from microorganisms. Biotechnology 10: 60-65.

Hanko, V.P. \& Rohrer, J.S. 2000. Determination of carbohydrates, sugar alcohols, and glycolsin cells cultures and fermentation broths using high-performance anion-exchange chromatogrpahy with pulsed amperometric detection. Anal. Biochem. 283: 192-199.

Isa, M.H.M., Coraglia, D., Frazier, R. \& Jauregi, P. 2007. Recovery and purification of surfactin from fermentation broth by a two-step ultrafiltration process. J. Membrane Sci. 296: 51-57.

Isa, M.H.M., Frazier, R. \& Jauregi, P. 2008. A further study of the recovery and purification of surfactin from fermentation broth by membrane filtration. J. Sep. Purif. Technol. 64: 176-182.

Joshi, S., Bhaucha, C. \& Desai, A.J. 2008. Production of biosurfactant and antifungal compound by fermented food isolat Bacillus subtilis 20B. Bioresource Technol. 99: 46034608.

Kim, H.S., Yoon, B.D., Lee, C.H., Oh, H.M., Katsuragi, T. \& Tani, Y. 1997. Production and properties of a lipopeptide biosurfactant from Bacillus subtilis C9. J. Fermentation Bioeng. 84: 41-46.

Kowall, M., Vater, J., Kluge, B., Stein, T., Franke, P. \& Ziessow, D. 1998. Separation and characterization of surfactin isoforms produced by Bacillus subtilis OKB 105. J. Colloid Interf. Sci. 204: 1-8.

Lin, S., Carswell, K., Sharma, M. \& Georgiau, G. 1994. Continuos production of the lipopeptide biosurfactant of Bacillus licheniformis JF-2. Appl. Microbiol. Biot. 41: 281-285.

Mulligan, C.N. 2005. Environmental applications for biosurfactants. Environ. Pollut. 133: 183-198.

Neves, L., Oliveira, K., Kobayashi, M., Penna, T. \& Converti, A. 2007. Biosurfactant production by cultivation of Bacillus atrophaeus ATCC 9372 in semidefined glucose/casein-based media. Appl. Biochem. Biotechnol. 136: 136-140.

Nitschke, M. \& Pastore, G. 2006. Production and properties of a surfactant obtained from Bacillus subtilis grown on cassava wastewater. Bioresource Technol. 97: 336-341.

Okpokwasili, G. \& Nweke, C. 2008. Microbial growth and substrate utilization kinetics. Afr. J. Biotechnol. 5(4): 305-317.

Ramirez, I.M., Tsaousi, K., Rudden, M., Marchant, R., Alameda, E.J., Roman, M.G. \& Banat, I.M. 2015. Rhamnolipid and surfactin production from olive oil mill waste as sole carbon source. Bioresource Technology 198: 231-236.

Rodrigues, L., Moldes, A., Teixeira, J. \& Oliveira, R. 2006. Kinetic study of fermentative biosurfactant production by Lactobacillus strain. J. Biochem. Eng. 28: 109-116.

Shannaq, M. \& Isa, M.H.M. 2013. Isolation and molecular identification of surfactin producing $B$. subtilis. International Conference on Biochemical, Pharmaceutical Sciences and Chemical Engineering, Kuala Lumpur.

Shepard, O. \& Mulligan, C. 1987. The production of surfactin by Bacillus subtilis grown on peat hydrolysate. Appl.Microbiol. Biot. 29: 110-116.
Singh, P. \& Cameotra, S. 2004. Potential applications of microbial surfactants in biomedical sciences. Trends Biotechnol. 22: 142-146.

Sousa, M., Dantas, I.T., Feitosa, F.X., Alencar, A.E.V., Soares, S.A., Melo, V.M.M., Goncalves, L.R.B. \& Sant'ana, H.B 2014. Performance of biosurfactant produced by Bacillus subtilis LAMI005 on the formation of iol/biosurfactant/ water emulsion: Study of phase behavior of emulsified systems. Brazilian Journal of Chemical Engineering 31: 613-623.

Wei, Y-H., Wang, M., Chang, J-S. \& Kung, S-S. 2003. Identification of induced acidification in iron-eniched cultures of Bacillus subtilis during biosurfactant fermentation. $J$. Biosci. Bioeng. 96: 174-178.

Wei, Y-H., Lai, C. \& Chang, J-S. 2007. Using Taguchi experimental design methods to optimize trace element composition for enhanced surfactin production by Bacillus subtilis ATCC 21332. Process Biochem. 42: 40-45.

Xiao, X., Chen, H., Wang, J. \& Ren, C. 2008. Impact of Bacillus subtilis JA, a biocontrol strain of fungal plant pathogens, on arbuscular mycorrhiza formation in zeamays. World $J$. Microb. Biot. 24: 1133-1137.

Yakimov, M., Amro, M. \& Bock, M. 1997. The potential of Bacillus licheniformis strains for in situ enhanced oil recovery. J. Petrol. Sci. Eng. 18: 147-160.

Zweers, J.C., Barak, L., Becher, D . \& Driessen, A. 2008. Towards the development of Bacillus subtilis as a cell factory for membrane proteins and protein complexes. J. Microb. Cell Fact. 7: 1-20.

Muhammad Qadri Effendy Mubarak, Siti Hajar Mohamad Jufri \& Shikh Mohd Shahrul Nizan Shikh Zahar

Faculty of Science and Technology

Universiti Sains Islam Malaysia

Bandar Baru Nilai

71800 Nilai, Negeri Sembilan Darul Khusus Malaysia

Mohd Sahaid Kalil

Faculty of Engineering and Built Environment

Universiti Kebangsaan Malaysia

43600 UKM Bangi, Selangor Darul Ehsan

Malaysia

Aidil Abdul Hamid

Faculty of Science and Technology

Universiti Kebangsaan Malaysia

43600 UKM Bangi, Selangor Darul Ehsan

Malaysia

Mohd Hafez Mohd Isa*

Faculty of Science and Technology

Universiti Sains Islam Malaysia

Bandar Baru Nilai

71800 Nilai, Negeri Sembilan Darul Khusus

Malaysia

*Corresponding author; email: m.hafez@usim.edu.my

Received: 7 June 2016

Accepted: 9 March 2017 